\title{
High-pressure homogenization of raw and pasteurized milk modifies the yield, composition, and texture of queso fresco cheese
}

\author{
D. Escobar, ${ }^{\star}$ S. Clark,† V. Ganesan,‡ L. Repiso, ${ }^{*}$ J. Waller,§ and F. Harte $\ddagger^{1}$ \\ *Laboratorio Tecnológico del Uruguay, Montevideo 11500, Uruguay \\ †Department of Food Science and Human Nutrition, Iowa State University, Ames 50011 \\ ‡Department of Food Science and Technology, and \\ §Department of Animal Science, University of Tennessee, Knoxville 37996
}

\section{ABSTRACT}

High-pressure homogenization (HPH) of milk was studied as an alternative processing operation in the manufacturing of queso fresco cheese. Raw and pasteurized $\left(65^{\circ} \mathrm{C}\right.$ for $\left.30 \mathrm{~min}\right)$ milks were subjected to $\mathrm{HPH}$ at 0, 100, 200, and $300 \mathrm{MPa}$ and then used to manufacture queso fresco. The cheeses were evaluated for yield, moisture content, titratable acidity, nitrogen content, whey protein content, yield force, yield strain, and tactile texture by instrumental or trained panel analyses. The combination of $\mathrm{HPH}$ and thermal processing of milk resulted in cheeses with increased yield and moisture content. The net amount of protein transferred to the cheese per kilogram of milk remained constant for all treatments except raw milk processed at $300 \mathrm{MPa}$. The highest cheese yield, moisture content, and crumbliness were obtained for thermally processed milk subjected to $\mathrm{HPH}$ at $300 \mathrm{MPa}$. The principal component analysis of all measured variables showed that the variables yield, moisture content, and crumbliness were strongly correlated to each other and negatively correlated to the variables yield strain, protein content (wet basis), and sensory cohesiveness. It is suggested that the combination of thermal processing and HPH promotes thermally induced denaturation of whey protein, together with homogenization-induced dissociation of casein micelles. The combined effect results in queso fresco containing a thin casein-whey matrix that is able to better retain sweet whey. These results indicate that $\mathrm{HPH}$ has a strong potential for the manufacture of queso fresco with excellent yield and textural properties.

Key words: queso fresco, Hispanic cheese, highpressure homogenization

Received September 28, 2010

Accepted December 7, 2010.

${ }^{1}$ Corresponding author: fede@utk.edu

\section{INTRODUCTION}

Queso fresco is a Hispanic-style cheese that has become a regular part of the Latin-American diet (Clark et al., 2004) and is increasingly popular among US consumers (USDA-NASS, 2010). Queso fresco is a fresh, soft, white, high-moisture, slightly salty cheese characterized by a crumbly texture and low meltability (Van Hekken and Farkye, 2003). It was traditionally made using raw bovine milk and consumed within $14 \mathrm{~d}$ of manufacture (Renye et al., 2008). Typical moisture ranges from 46 to $57 \%$ (wet basis), $\mathrm{NaCl}$ is 1 to $3 \%$ (wt/wt), and $\mathrm{pH}$ is about 6.1 (Hwang and Gunasakaran, 2001; Tunick, 2006). Queso fresco made from raw milk provides growth-promoting conditions for pathogenic bacteria, including Listeria monocytogenes and Salmonella typhimurium, and it has been linked to several foodborne outbreaks and recalls (Altekruse et al., 1998; Cody et al., 1999; Villar et al., 1999; Hise et al., 2004; MacDonald et al., 2005; FDA, 2010a,b). Current US regulations prohibit the commercialization of queso fresco manufactured from raw milk, and only cheese made from pasteurized milk and commercial starter cultures can be sold. However, many traditional consumers consider that thermal pasteurization of milk modifies the organoleptic properties of the final product.

Several nonthermal food preservation processes are being studied (e.g., high hydrostatic pressure), with the aims of replacing thermal processing primarily in foods that are consumed fresh or minimally processed. Because of the legal requirement for pasteurization of milk for fresh cheeses such as queso fresco, alternative processing techniques are considered as additions, not substitutions, for pasteurization.

Valve homogenization at pressure $<20 \mathrm{MPa}$ is a nonthermal technology currently used by the dairy industry to prevent creaming in fluid milk by reducing the fat globule radius ( $\mathrm{r}$ ), thus lowering its terminal velocity $\left(\mathrm{v}_{\mathrm{t}} ; \mathrm{v}_{\mathrm{t}} \sim \mathrm{r}^{2}\right)$. High-pressure valve homogenization $(\mathbf{H P H})$ is a similar process but with operating 
pressure up to $400 \mathrm{MPa}$, in which a combination of physical phenomena (shear stress, hydrostatic pressure, cavitation, turbulence, and temperature) modifies the physicochemical properties of the processed fluid food and promotes microbial inactivation. High-pressure homogenization has been used to inactivate pathogenic and spoilage microorganisms in fluid foods (Lanciotti et al., 1994, 1996; Kheadr et al., 2002; Wuytack et al., 2002; Thiebaud et al., 2003; Hayes et al., 2005; Pereda et al., 2007; Taylor et al., 2007) and to modify the functionality of protein and fat constituents in milk (Paquin, 1999; Hayes and Kelly, 2003a,b; Sandra and Dalgleish, 2005; Iucci et al., 2007; Roach and Harte, 2008).

In recent years, the use of HPH for cheese manufacture has been studied for its potential to reduce microbial populations in raw milk, combined with changes in yield and physicochemical properties of cheese. Lanciotti et al. (2007) found a reduction of biogenic amines in Caciotta and Pecorino cheeses obtained from milk processed by HPH. Changes in lipolytic and proteolytic patterns were found during the ripening of Italian (Lanciotti et al., 2006; Vannini et al., 2008) and goat cheeses (Guerzoni et al., 1999; Buffa et al., 2005) manufactured using HPH-treated milks.

The objective of this work was to determine yield, composition, texture, and organoleptic properties of queso fresco made from raw and pasteurized milk processed by HPH up to $300 \mathrm{MPa}$.

\section{MATERIALS AND METHODS}

\section{Milk Processing}

Raw whole milk was collected from the University of Tennessee Institute of Agriculture dairy farm located in Knoxville, Tennessee. Milk was pasteurized by heating at $65^{\circ} \mathrm{C}$ for $30 \mathrm{~min}$ in a pilot-scale water bath. Then, 2 $\mathrm{L}$ of raw or pasteurized milk was subjected to $\mathrm{HPH}$ at 0, 100, 200, and $300 \mathrm{MPa}$ using a 2-stage continuous high-pressure valve homogenizer (model FPG 12500, Stanstead Fluid Power, Essex, UK) equipped with a data logger, which recorded pressure and temperature immediately after the secondary pressure valve. An approximate $18^{\circ} \mathrm{C}$ increase in temperature was recorded for every $100-\mathrm{MPa}$ increment in pressure. A heat exchanger connected immediately after the secondary pressure valve cooled the samples to approximately $5^{\circ} \mathrm{C}$ in less than $2 \mathrm{~s}$. A total of 8 queso fresco treatment combinations were made from raw and pasteurized whole milk subjected to HPH from 0 to $300 \mathrm{MPa}$. Three independent queso fresco cheeses were made for each treatment combination.

\section{Preparation of Queso Fresco}

Each individual cheese was made from an initial 2-kg mass of treated milk. The cheeses were manufactured according to the method developed by Clark et al. (2001). Briefly, the processed milk was heated to $32^{\circ} \mathrm{C}$ and $0.26 \mathrm{~g}$ of starter culture (Choozit MA 11 LYC 50 DCU, Danisco Inc., Scarborough, ON, Canada) was added. Thirty minutes later, $0.26 \mathrm{~mL}$ of coagulant (DCI Supreme Rennet, Dairy Connection Inc., Madison, WI) was added, and the cultured milk was allowed to set for approximately $30 \mathrm{~min}$. The curd was cut in approximately $10-\mathrm{mm}^{3}$ cubes and allowed to heal for 10 min before cooking. Curd and whey were heated to $38^{\circ} \mathrm{C}$ over $30 \mathrm{~min}$ (stirring continuously), and then the temperature was maintained and curd was stirred continuously for an additional 30 min. After cooking, the first half of the whey was drained. Ten minutes later, the first one-third of total salt was added at a rate of $10 \mathrm{~g} / \mathrm{kg}$ of milk, mixed briefly, and left undisturbed for $10 \mathrm{~min}$. After $10 \mathrm{~min}$, one-quarter of the whey was drained and the second one-third of salt was added and stirred in. After $5 \mathrm{~min}$, the final amount of whey was drained and the rest of the salt was added and then stirred in for $5 \mathrm{~min}$. The curd obtained was pressed in a perforated polyvinyl chloride cylinder (diameter $=11.1 \mathrm{~cm}$ ) under $2.275 \mathrm{MPa}$ pressure for $1 \mathrm{~h}$ at room temperature $\left(\sim 23^{\circ} \mathrm{C}\right)$. After the pressing step, each cheese was removed from the cylinder and crumbled. Subsequently, the crumbled cheese was pressed in the same hoop for another $20 \mathrm{~h}$.

\section{Total Protein, Moisture, and Yield}

Crumbled cheese samples were analyzed in duplicate. Moisture was obtained by oven drying at $102^{\circ} \mathrm{C}$ following AOAC method 948.12 (AOAC, 1990) and protein content following AOAC method 990.03 (AOAC, 1990) using a Leco FP-2000 nitrogen analyzer (Leco, St. Joseph, MI). Cheese yield was calculated as the percentage ratio between mass of cheese over mass of initial milk (yield $=100 \times \mathrm{g}$ of cheese $/ \mathrm{g}$ of initial milk).

\section{SDS-PAGE}

An approximately 50-g sample of each cheese was kept frozen $\left(-20^{\circ} \mathrm{C}\right)$ for SDS-PAGE. After thawing the cheese at room temperature for $1 \mathrm{~h}$, proteins were extracted using the method described by Ong et al. (2006), with modifications. Briefly, an aliquot of each cheese sample $(0.05 \mathrm{~g})$ was suspended in $1 \mathrm{~mL}$ of Tris $(10 \mathrm{~m} M)$-EDTA $(1 \mathrm{mM}) \mathrm{pH} 8.0$ buffer, $350 \mu \mathrm{L}$ of $10 \%$ SDS, and $50 \mu \mathrm{L}$ of $\beta$-mercaptoethanol. The samples 
Table 1. Texture attributes definition and anchors determined by the trained panel

\begin{tabular}{|c|c|c|c|c|}
\hline Category & Procedure & Attribute & Definition & Anchors \\
\hline Texture before breaking & $\begin{array}{l}\text { Lift the sample from plate and press the } \\
\text { sample gently for } 1 \text { to } 2 \mathrm{~s} \text { without breaking }\end{array}$ & Springiness & $\begin{array}{l}\text { Rate at which the cheese springs } \\
\text { back to original shape and height } \\
\text { after compressed }\end{array}$ & $\begin{array}{l}3=\text { Cream cheese } \\
6=\text { Mozzarella } \\
10=\text { Swiss } \\
15=\text { Parmesan } \\
0=\text { Cream cheese } \\
5=\text { Mozzarella } \\
12=\text { Swiss } \\
15=\text { Parmesan }\end{array}$ \\
\hline \multirow[t]{3}{*}{ Texture during breaking } & \multirow[t]{3}{*}{$\begin{array}{l}\text { Manipulate the sample using thumb } \\
\text { and } 2 \text { fingers } 5 \text { times }\end{array}$} & Crumbliness & $\begin{array}{l}\text { Ease of sample to break apart } \\
\text { or crumble during manipulation }\end{array}$ & $\begin{array}{l}0=\text { Cream cheese } \\
3=\text { Swiss } \\
7=\text { Sharp Cheddar } \\
13=\text { Feta }\end{array}$ \\
\hline & & Stickiness & $\begin{array}{l}\text { How much the sample sticks } \\
\text { to the fingers during manipulation }\end{array}$ & $\begin{array}{l}1=\text { Swiss } \\
6=\text { Sharp Cheddar } \\
9=\text { Feta } \\
15=\text { Cream cheese }\end{array}$ \\
\hline & & Cohesiveness & $\begin{array}{l}\text { How well the sample holds } \\
\text { together during manipulation }\end{array}$ & $\begin{array}{l}2=\text { Feta } \\
8=\text { Swiss } \\
11=\text { Mozzarella } \\
15=\text { Cream cheese }\end{array}$ \\
\hline Residuals left after breaking & $\begin{array}{l}\text { Feel any tactile residual (left over) } \\
\text { on the fingers }\end{array}$ & Oiliness/greasiness residual & $\begin{array}{l}\text { How much oil or grease residual } \\
\text { film is left on the fingers } \\
\text { after manipulation }\end{array}$ & $\begin{array}{l}4=\text { Swiss } \\
6=\text { Sharp Cheddar } \\
9=\text { Feta } \\
11=\text { Mozzarella } \\
15=\text { Cream cheese }\end{array}$ \\
\hline
\end{tabular}




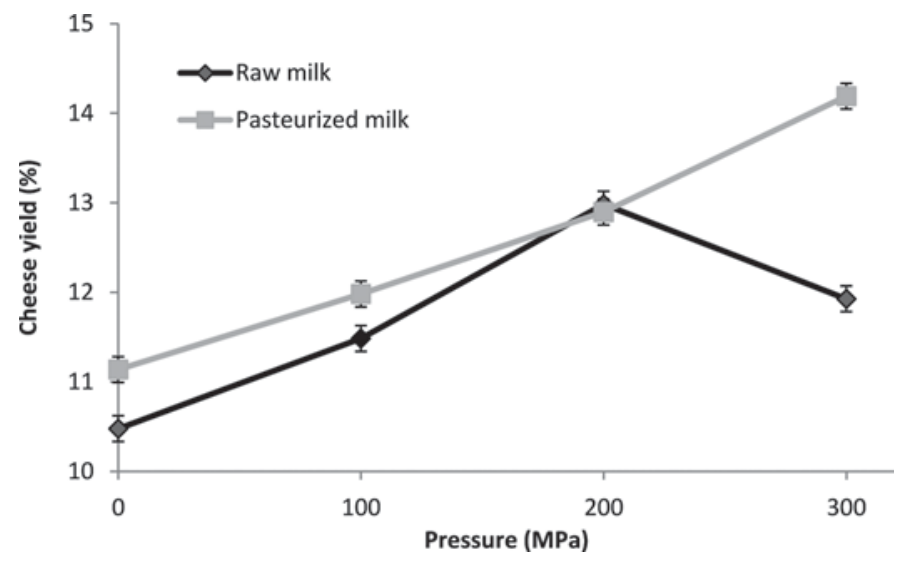

Figure 1. Yield (wt/wt \%) of queso frescos made from raw and pasteurized milk subjected to high-pressure homogenization. Bars are $95 \%$ CI.

were agitated for approximately $1 \mathrm{~h}$, until the cheese solids were completely dispersed.

Electrophoresis was done following the procedure described by Laemmli (1970) using a mini-protean II gel electrophoresis unit (Bio-Rad, Hercules, CA). One hundred microliters of protein dispersion was diluted in 400 $\mu \mathrm{L}$ of sample buffer $(62.5 \mathrm{~m} M$ Tris- $\mathrm{HCl}, \mathrm{pH} 6.8,20 \%$ glycerol, $2 \%$ SDS, $5 \% \beta$-mercaptoethanol, and $0.025 \%$ bromophenol blue) and then heated for 5 min at $95^{\circ} \mathrm{C}$. A working volume of $15 \mu \mathrm{L}$ of each sample and $10 \mu \mathrm{L}$ of standards $(\alpha-\mathrm{CN}, \beta-\mathrm{CN}$, and $\beta$-LG; Sigma-Aldrich, Milwaukee, WI) were loaded into the wells of $15 \%$ polyacrylamide ready-gel (Bio-Rad) and run at a constant $200 \mathrm{~V}$ for $40 \mathrm{~min}$ at room temperature. Proteins were stained using $0.25 \%$ (wt/vol) Coomassie Brilliant Blue R-250 [50\% methanol, 10\% acetic acid, 0.25\% (wt/vol) Coomassie Blue] during 10 min and then destained with

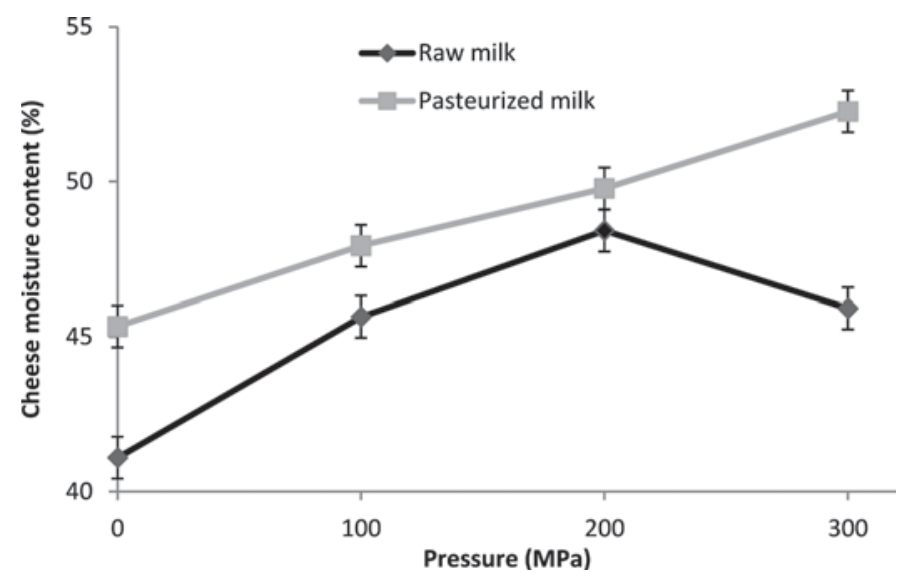

Figure 2. Moisture content (wt/wt \%) of queso frescos made from raw and pasteurized milk subjected to high-pressure homogenization. Bars are $95 \%$ CI.
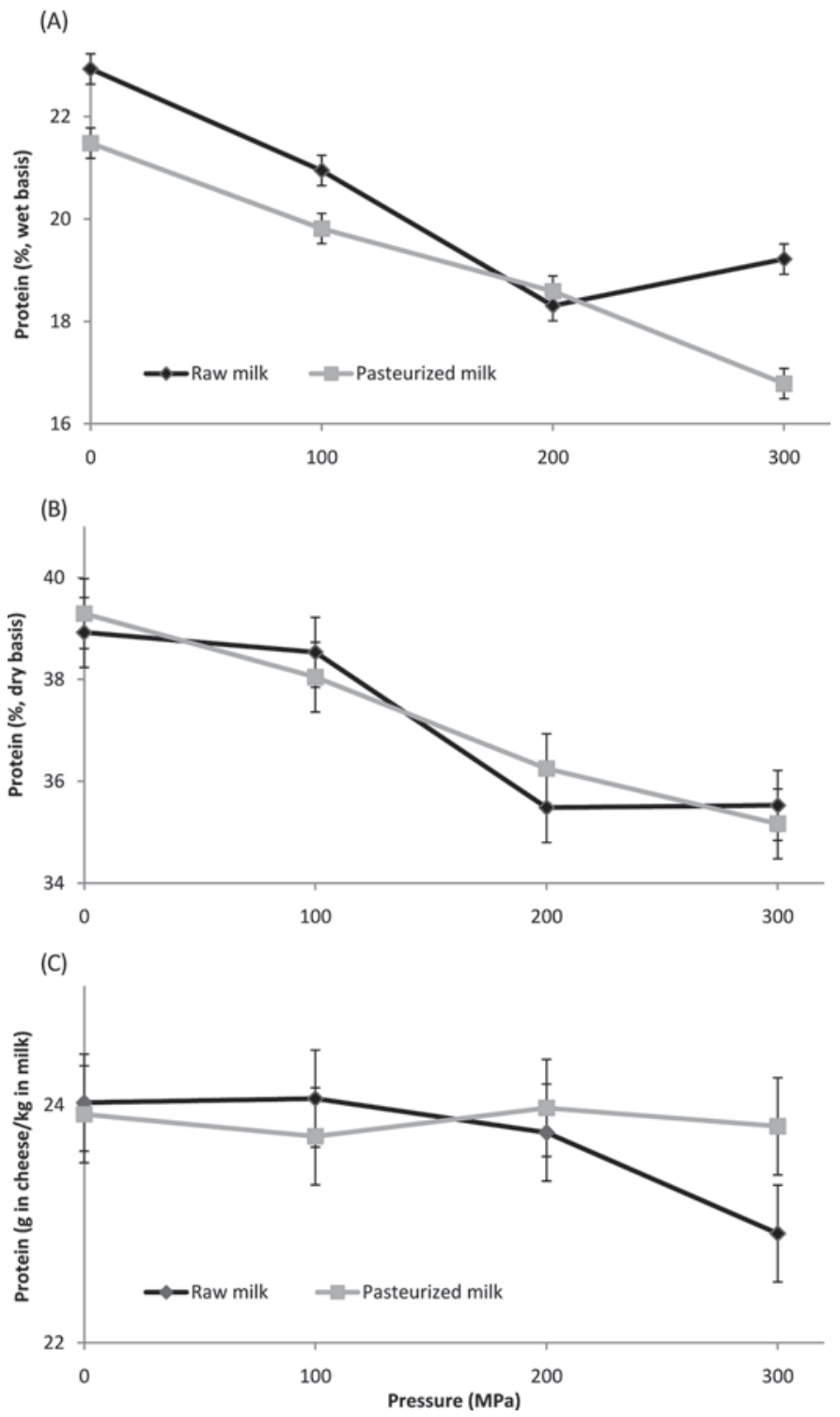

Figure 3. Protein content of queso frescos made from raw and pasteurized milk subjected to high-pressure homogenization: (A) weight percent dry basis; (B) weight percent wet basis; (C) grams of protein in cheese per kilogram of protein in milk. Bars are $95 \%$ CI.

deionized water containing $15 \%$ (vol/vol) methanol and $10 \%$ (vol/vol) acetic acid.

\section{Sensory Evaluation}

A group of 9 students was selected from the Food Science and Technology Department at the University of Tennessee-Knoxville and given 6 training sessions (1 $\mathrm{h}$ each) on tactile evaluation of a range of commercially available cheeses used as anchors. The sensory evaluation of queso fresco was performed after $2 \mathrm{~d}$ of manufacturing. Six cheese attributes, grouped into 3 catego- 
(1)

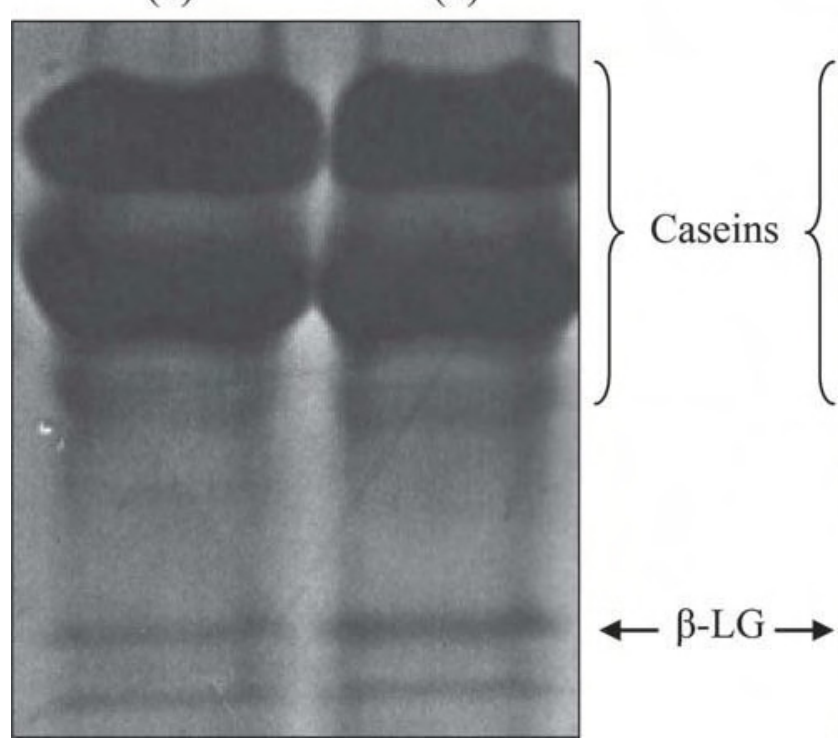

(3)

(4)
Figure 4. The SDS-PAGE profiles of queso fresco made from (1) raw milk, (2) pasteurized milk, (3) raw milk homogenized at 300 MPa, (4) pasteurized milk homogenized at $300 \mathrm{MPa}$.

ries, were evaluated: texture before breaking (firmness and springiness), texture during breaking (crumbliness, stickiness, and cohesiveness), and oiliness/greasiness residual after crumbling. The texture terms, anchors, and cheese standards selected for the hand evaluation are shown in Table 1. A 16-point scale based on Sandra et al. (2004b) was used, where $0=$ none, $3=$ slight, $7=$ moderate, and $15=$ extreme. Experimental cheese samples were cut in $\sim 1.5-\mathrm{cm}^{3}$ cubes and allowed to equilibrate at room temperature for 30 min before sensory evaluation. The cheese cubes were identified using randomly generated 3 -digit codes and randomly presented to the trained panelists. The panelists were provided with 3 cheese cubes per test evaluation for descriptive cheese texture analysis.

\section{Uniaxial Compression Test}

Cheeses were stored for $2 \mathrm{~d}$ at $4^{\circ} \mathrm{C}$ and then cut into $12-\mathrm{mm}^{3}$ cubes. The cubes were kept in plastic containers to prevent water loss and equilibrated to room temperature for $30 \mathrm{~min}$ before analysis. The compression test was done using a texture analyzer (TA-XT Plus, Texture Technology Corp., Stable Microsystems, Scarsdale, NY) with a 5 -kg load cell. The cheese cubes were compressed to $80 \%$ of their original height using a 3.5-cm-diameter cylindrical probe moving at a displacement speed of $0.4 \mathrm{~mm} / \mathrm{s}$. The inflection point in the force versus strain curve was used to calculate the cheese initial force and yield strain fracture. Overall means of 18 determinations (6 determinations per cheese, 3 cheeses per treatment) are reported in this manuscript.

\section{Statistical Analysis}

Experiments were analyzed as a completely randomized design with 3 replicates. Analysis of variance was done using SAS software (version 9.2, SAS Institute Inc., Cary, NC). In cases where a significant treatment effect was found, Student's least significant difference multiple comparison test $(\alpha=0.05)$ was done to test for differences among individual treatment means. Principal component analysis of average values for sensory determinations, texture, yield, moisture, and protein content was done to illustrate the relationship among the various parameters using the XLSTAT-Pro 2010 Excel add-in (Addinsoft, New York, NY).

\section{RESULTS AND DISCUSSION}

The combined thermal and HPH processing of milk resulted in better cheese yield and queso frescos containing higher moisture content compared with cheeses made with raw or HPH-only milks (Figures 1 and 2 ). In cheeses made from thermally pasteurized milk, the increase in yield was linearly related to the homogenization pressure from 0 to $300 \mathrm{MPa}$, with a $1 \%$ increment in final yield for every 100-MPa increment in homogenization pressure [yield $=11.04 \%+(1.01 \times$ homogenization pressure); $\left.\mathrm{r}^{2}=0.98 ; P<0.01\right]$. However, cheeses made from raw milk showed an increase 


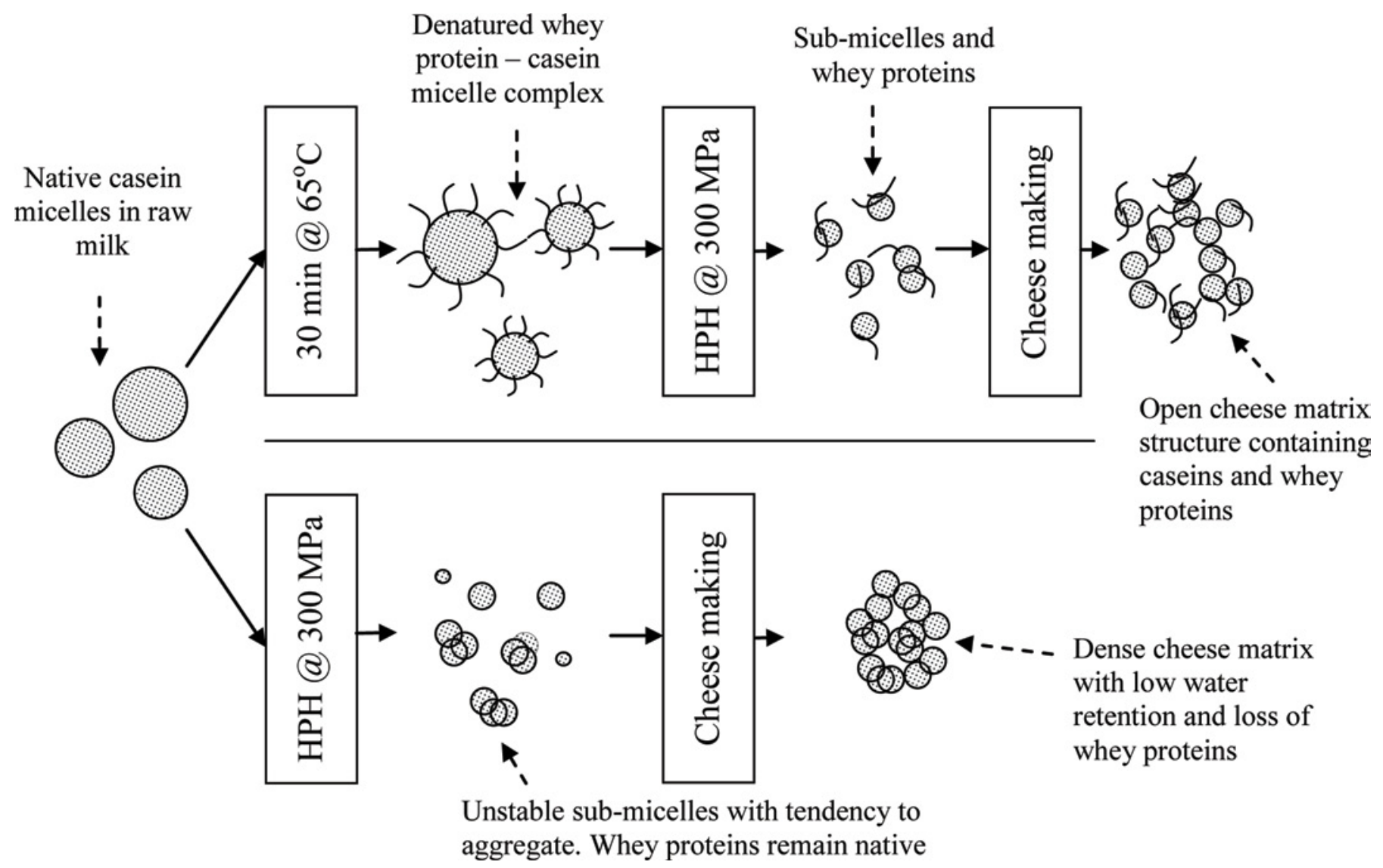

Figure 5. Diagram showing suggested changes in the structure of queso fresco made from raw and pasteurized milk homogenized at 300 MPa ( $\mathrm{HPH}=$ high-pressure homogenization).

in yield and moisture content that was proportional to the homogenization pressure only up to $200 \mathrm{MPa}$, and a sharp decrease in both yield and moisture content when raw milk was subjected to homogenization at $300 \mathrm{MPa}$ (Figures 1 and 2). The increased cheese yield and moisture content in cheeses made from raw milk processed with homogenization up to $200 \mathrm{MPa}$ was consistent with previous reports in cheeses made with caprine and bovine milks homogenized up to $100 \mathrm{MPa}$ (Guerzoni et al., 1999; Lanciotti et al., 2004, 2006; Zamora et al., 2007; Burns et al., 2008; Vannini et al., 2008). These authors attributed the better yield to an increase in the water-holding capacity of proteins and to higher whey protein retention during curd formation.

The cheese protein content on a wet basis followed an inverse relationship with homogenization pressure (Figure 3A) and was negatively correlated to cheese moisture content $(\mathrm{r}=-0.94, P<0.01)$ and cheese yield $(\mathrm{r}=-0.97, P<0.01)$, which was consistent with better cheese yields explained by higher moisture retention. However, the cheese protein content on a dry basis exhibited a negative simple linear regression with respect to homogenization pressure $\left(\left(\mathrm{r}^{2}=0.99, P<0.01\right.\right.$;
Figure 3B) for both raw and pasteurized milks, with an average $1.4 \%$ reduction in total protein content on a dry basis for every $100-\mathrm{MPa}$ increment in homogenization pressure. The relative reduction of total protein

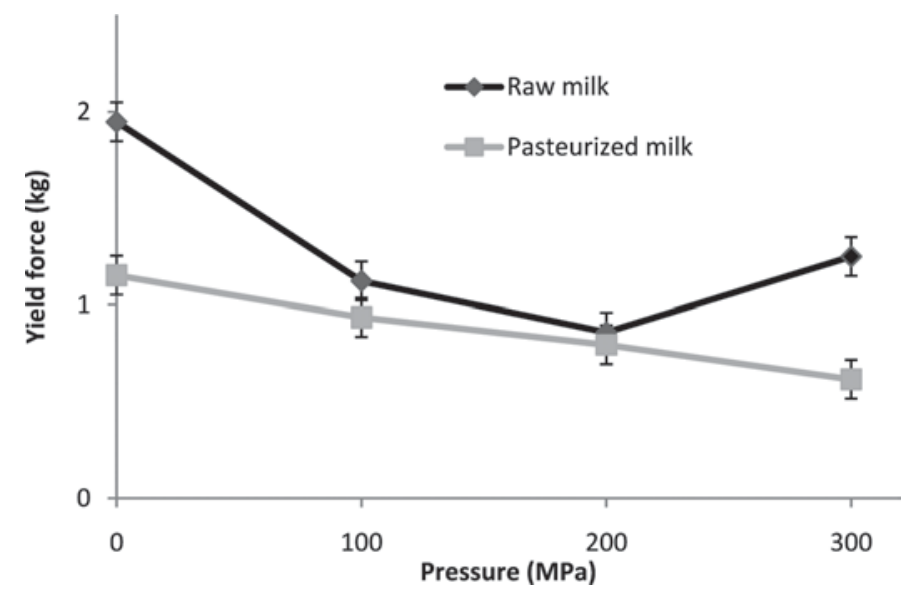

Figure 6. Force at first peak during uniaxial compression of queso fresco made from raw and pasteurized milk subjected to high-pressure homogenization. Bars are 95\% CI. 


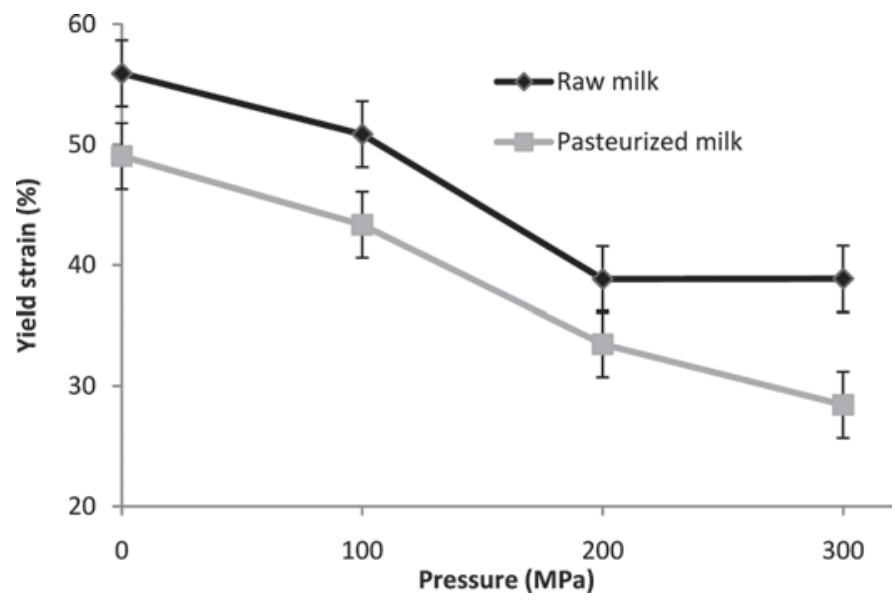

Figure 7. Strain at first peak during uniaxial compression of queso fresco made from raw and pasteurized milk subjected to high-pressure homogenization. Bars are 95\% CI.

content on a dry basis suggests that the homogenization process promoted better lactose and fat retention in the cheese. This is hypothetical, because residual lactose and fat contents were not measured in the cheeses. However, sweet whey has a high lactose content and HPH is known to improve the emulsifying properties of the casein micelles, which could improve fat retention in cheese (San Martin-González et al., 2009).

The net amount of protein in milk that was transferred to the cheese ( $\mathrm{g}$ of protein in cheese $/ \mathrm{kg}$ of protein in milk) remained essentially constant for all processing conditions, with the exception of raw milk processed at $300 \mathrm{MPa}$ (Figure 3C), in which a sharp decrease in the net amount of protein transferred to cheese was observed. This was an indication that more protein was lost in the sweet whey during curd formation, when extreme homogenization conditions were used in raw milk.

The protein patterns from the SDS-PAGE gels revealed a stronger retention of whey proteins ( $\beta-\mathrm{LG}$ and $\alpha$-LA) in cheese when a combined thermal and $300 \mathrm{MPa}$ homogenization pressure was used to process the milk (Figure 4). However, electrophoretic bands corresponding to whey proteins in cheeses made from raw milk processed with only $\mathrm{HPH}$ at $300 \mathrm{MPa}$ (Figure 4) showed relatively lower concentrations than the combined HPH and thermal treatment. Although the homogenization of milk resulted in shear-induced increases of temperature (approximately $18^{\circ} \mathrm{C}$ for every $100-\mathrm{MPa}$ increase in homogenization pressure), the use of a heat exchanger immediately after the homogenization valve promoted rapid cooling of the milk $(<2 \mathrm{~s})$, and extensive denaturation of whey protein was prevented. The SDS gels of cheeses made from raw milk processed at 300 $\mathrm{MPa}$ exhibited $\beta$-LG bands similar to those of control cheeses made from raw milk. Furthermore, even though the milk processed at $300 \mathrm{MPa}$ reached about $80^{\circ} \mathrm{C}$ immediately after the homogenization valve, exposure was so limited that cheese made from raw milk processed at $300 \mathrm{MPa}$ exhibited evidence of enzymatic rancidity due to active lipase enzymes. These observations were consistent with reports by Pereda et al. (2008, 2009), in which limited shear-induced damage was observed in various milk components, including whey proteins.

The constant amount of total protein transferred from milk to cheese and the evidence of increased whey retention in cheeses made from pasteurized and homogenized milk would suggest that some casein may be lost in the sweet whey and some whey proteins are retained in the cheese curd. Roach and Harte (2008) found a decrease in the apparent casein micelle size from 0 to $200 \mathrm{MPa}$ but an increase in micelle diameter in the range from 250 to $350 \mathrm{MPa}$ due to instability and coalescence. It was hypothesized that the pressureand shear-induced dissociation of the casein micelles at pressure $>200 \mathrm{MPa}$ was masked by rapid aggregation of casein submicelles due to temperature-induced hydrophobic interactions, resulting in relatively larger and unstable reformed casein micelles.

Figure 5 summarizes the suggested structural differences between cheeses made from raw and thermally pasteurized milk processed at $300 \mathrm{MPa}$. Thermal processing promotes extensive whey protein denaturation and interaction with $\kappa$-casein in the surface of the casein micelle (Fox and McSweeney, 1998). It is hypothesized that denatured whey proteins would protect the casein micelles from excessive HPH dissociation and would also constitute physical barriers against the re-formation of dense casein aggregates during curd formation, resulting in queso fresco with a relatively open structure and high moisture retention. In the case of cheeses made from raw milk homogenized at 300 $\mathrm{MPa}$, little whey protein denaturation is achieved and the dissociated micelles re-form into dense aggregates, resulting in cheeses with higher density and relatively lower moisture and whey protein retention.

The yield force, defined as the force exerted at the point where the cheese samples started breaking during uniaxial compression, is shown in Figure 6. In the case of cheeses made from thermally pasteurized milk, the yield force decreased linearly with increasing homogenization pressure. For queso fresco made from $\mathrm{HPH}-$ treated raw milk, a similar decrease in yield force was observed, but with homogenization pressure up to 200 MPa. The overall yield force for all cheeses exhibited a strong negative correlation with cheese moisture content $(\mathrm{r}<-0.96 ; P<0.001)$ and cheese yield $(\mathrm{r}<-0.86 ; P$ $<0.01)$ and a positive correlation with protein content on a wet basis $(\mathrm{r}>0.86 ; P<0.01)$. 
(A) $0 \mathrm{MPa}$

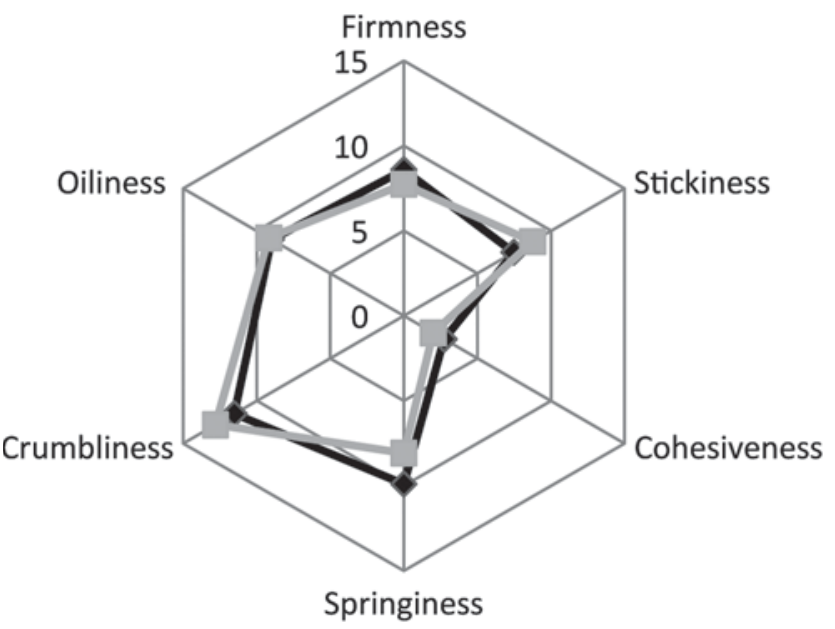

(B) $100 \mathrm{MPa}$

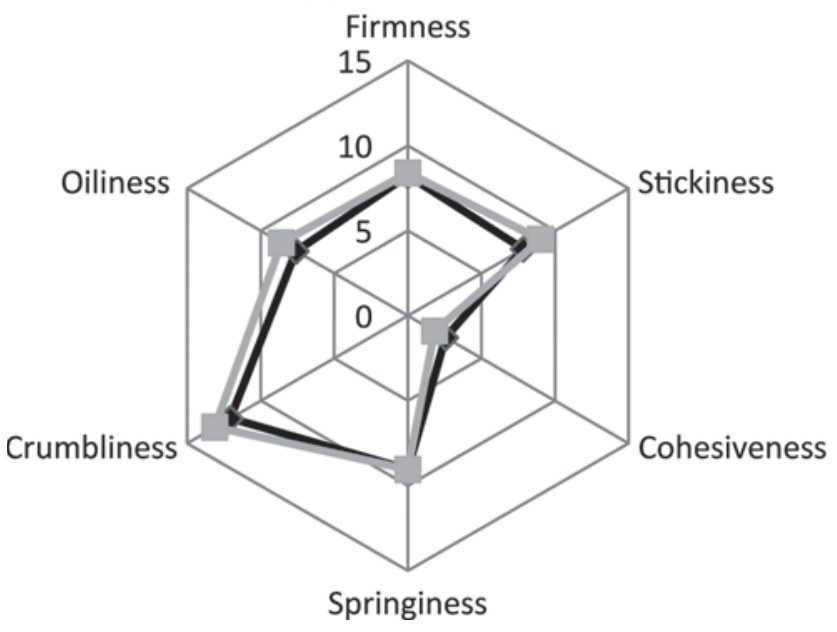

(C) $200 \mathrm{MPa}$

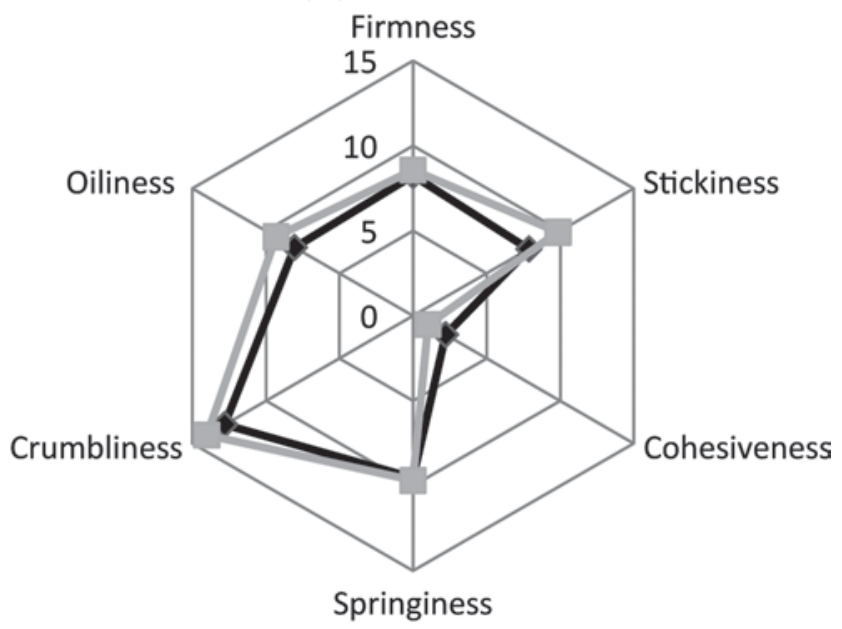

(D) $300 \mathrm{MPa}$

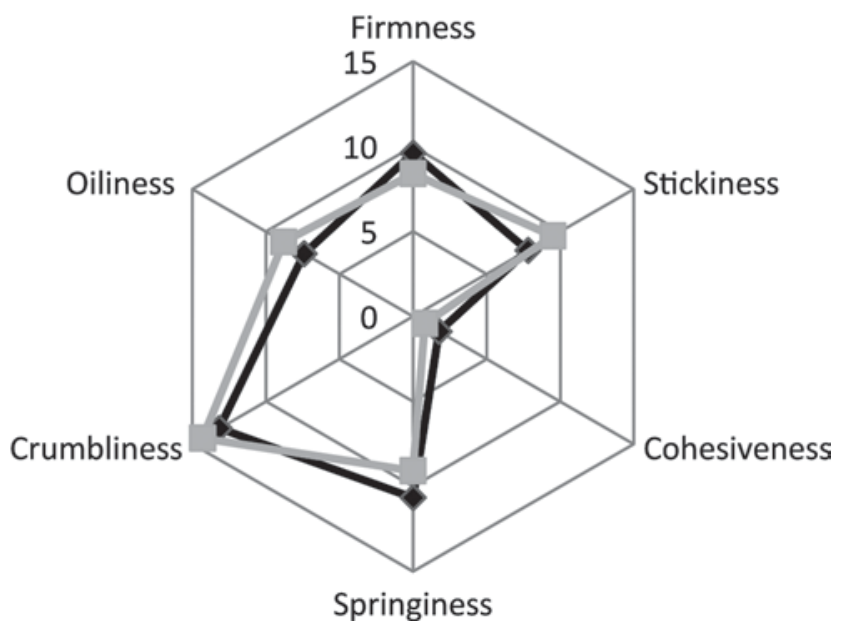

Figure 8. Scores by trained panelists for 6 texture descriptors of queso fresco made from raw (black line) and pasteurized (gray line) milk processed at 0 to $300 \mathrm{MPa}$ homogenization pressure.

Sandra et al. (2004a) found that queso fresco made from milk subjected to high hydrostatic pressure (400 $\mathrm{MPa}, 20 \mathrm{~min}$ ) needed less maximum force to compress during $80 \%$ compression and exhibited less perceived sensory firmness compared with cheeses made from raw milk. Whereas high hydrostatic pressure and HPH are different processes, it is known that the processing of milk with high hydrostatic pressure at 250 to $400 \mathrm{MPa}$ for $>1$ min promotes extensive casein dissociation (Harte et al., 2007). Figure 7 shows the relationship between yield strain (strain where the cheese begins to crumble during uniaxial compression) and homogenization pressure for cheese made from raw and thermally processed milks. The behavior was similar to the observed yield force, with a negative correlation with cheese moisture content $(\mathrm{r}<-0.92 ; P<0.01)$ and cheese yield $(\mathrm{r}<$ $-0.94 ; P<0.01)$, and a positive correlation with protein content on a wet basis $(\mathrm{r}>0.97 ; P<0.01)$.

Average scores for the tactile sensory evaluation of queso frescos made from raw and pasteurized milks processed by HPH are shown in Figure 8. All cheeses followed similar sensory attribute patterns, resulting in comparable radar charts.

The sensory attribute crumbliness, which is a key quality attribute for queso fresco, exhibited a linear regression in response to the homogenization of milk for both raw milk (crumbliness $=11.5+0.0056 \times \mathrm{HPH}$; $\mathrm{R}^{2}=0.952$ ) and pasteurized milk (crumbliness $=12.7$ $\left.+0.0054 \times \mathrm{HPH} ; \mathrm{R}^{2}=0.987\right)$. A constant difference of about 1 in the 15 -point sensory scale was observed 


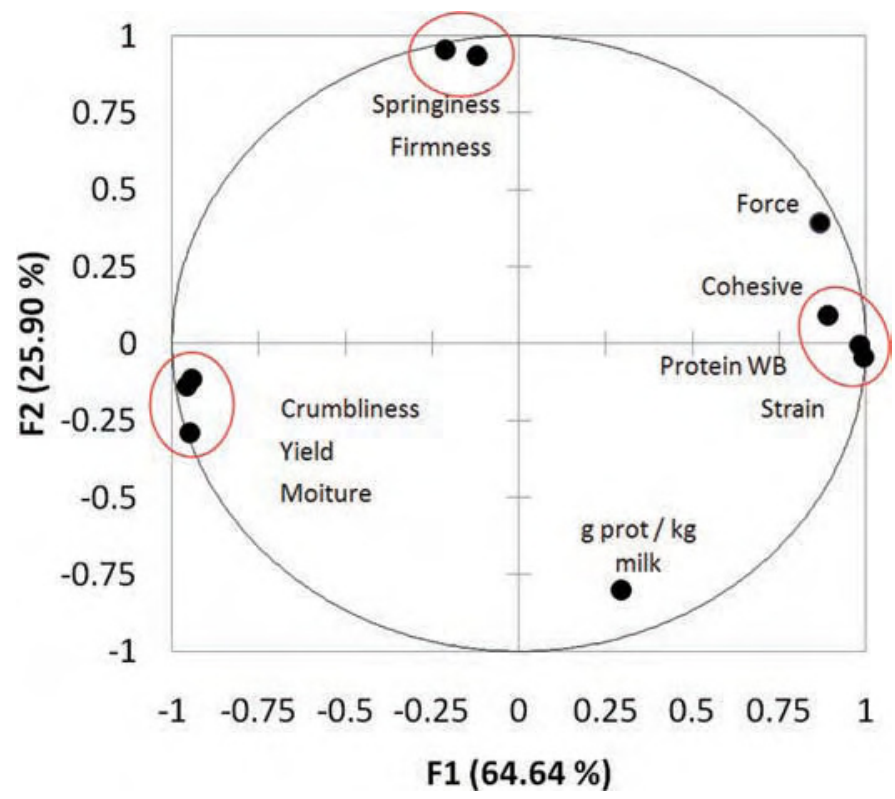

Figure 9. Principal component analysis (PCA) of the various measured parameters in cheeses made from raw and pasteurized milk processed with high-pressure homogenization. Prot = protein; $\mathrm{WB}=$ wet basis. Color version available in the online PDF.

for cheeses from pasteurized versus raw milk, regardless of the homogenization pressure. The best crumbliness score was observed in cheeses made from pasteurized milk processed at $300 \mathrm{MPa}$. In this case, some judges considered that crumbliness was "out of scale" and above the maximum allowable score of 15 . The sensory attribute cohesiveness exhibited a strong negative correlation $(\mathrm{r}<-0.98 ; P<0.01)$ with the attribute crumbliness.

These results further highlight the differences between processing using HPH versus high hydrostatic pressure, because most reports suggest that cheeses made from milk processed using high hydrostatic pressure exhibit lower crumbliness scores compared with controls made from raw milk (Sandra et al., 2004a; Hnosko, 2007).

A principal component analysis was done using all measured variables exhibiting significant correlations in cheeses made from raw and pasteurized milk subjected to 0 to $300 \mathrm{MPa}$ homogenization pressure (Figure 9). Two principal components explained $90.5 \%$ of the observed variability. The group integrated by the variables sensory crumbliness, yield, and moisture content showed strong correlation with each other and negative correlation with the group integrated by the variables protein on a wet basis, yield strain, and sensory cohesiveness. On the other hand, the variables sensory springiness and sensory firmness were grouped together and exhibited negative correlation with the variable grams of protein in cheese per kilogram of milk. The crumbly nature of queso fresco also resulted in a lack of correlation between the sensory perception of firmness and the yield force measured by a texture analyzer $(\mathrm{r}<$ $0.19 ; P>0.05)$, contrary to data reported by Hort et al. (1997) in Cheddar cheese.

\section{CONCLUSIONS}

The combined processing of milk using thermal pasteurization and HPH from 100 to $300 \mathrm{MPa}$ promotes modifications in the constituents of milk, leading to strong changes in yield, moisture content, and sensory properties of queso fresco. Our results and previous reports suggest that the better yield and moisture retention properties of cheeses made from thermally processed milk subjected to $300 \mathrm{MPa}$ pressure are the result of thermal-induced denaturation of whey proteins, together with homogenization-induced dissociation of casein micelles. These combined effects result in queso fresco containing a thin casein-whey protein matrix structure able to better retain sweet whey. The combined use of HPH and thermal processing of milk offers a potential to increase yield, moisture content, and textural quality of queso fresco.

\section{REFERENCES}

Altekruse, S. F., B. B. Timbo, J. C. Mowbray, N. H. Bean, and M. E. Potter. 1998. Cheese-associated outbreaks of human illness in the United States, 1973 to 1992: Sanitary manufacturing practices protect consumers. J. Food Prot. 61:1405-1407.

AOAC. 1990. Official Methods of Analysis, 15th ed. Association of Official Analytical Chemists, Washington, DC.

Buffa, M., B. Guamis, and A. J. Trujillo. 2005. Specific effect of highpressure treatment of milk on cheese proteolysis. J. Dairy Res. 72:385-392.

Burns, P., F. Patrignani, D. Serrazanetti, G. C. Vinderola, J. A. Reinheimer, R. Lanciotti, and M. E. Guerzoni. 2008. Probiotic Crescenza cheese containing Lactobacillus casei and Lactobacillus acidophilus manufactured with high-pressure homogenized milk. J. Dairy Sci. 91:500-512.

Clark, S., V. Hillers, and J. Austin. 2004. Improving the safety of Queso Fresco through intervention. Food Prot. Trends 24:419-422.

Clark, S., H. Warner, and L. Luedecke. 2001. Acceptability of Queso Fresco cheese by traditional and nontraditional consumers. Food Sci. Technol. Int. 7:165-170.

Cody, S. H., S. L. Abbott, A. A. Marfin, B. Schulz, P. Wagner, K. Robbins, J. C. Mohle-Boetani, and D. J. Vugia. 1999. Two outbreaks of multidrug-resistant Salmonella serotype Typhimurium DT104 infections linked to raw-milk cheese in Northern California. JAMA 281:1805-1810.

FDA. 2010a. Azteca Linda Corp. Recalls Queso Fresco and Queso Hebra Because of Possible Risk of Health. Vol. 2010. http://www.fda. gov/Safety/Recalls/ucm217902.htm. FDA, Washington, DC.

FDA. 2010b. Del Bueno Amends Recall of Queso Fresco Cheese Because of Possible Health Risk. Vol. 2010. http://www.fda.gov/ Safety/Recalls/ucm207627.htm. FDA, Washington, DC.

Fox, P. F., and P. L. H. McSweeney. 1998. Dairy Chemistry and Biochemistry. Chapman \& Hall, New York, NY.

Guerzoni, M. E., L. Vannini, C. Chaves Lopez, R. Lanciotti, G. Suzzi, and A. Gianotti. 1999. Effect of high pressure homogenization on microbial and chemico-physical characteristics of goat cheeses. J. Dairy Sci. 82:851-862. 
Harte, F. M., S. R. Gurram, L. O. Luedecke, B. G. Swanson, and G. V. Barbosa-Canovas. 2007. Effect of high hydrostatic pressure and whey proteins on the disruption of casein micelle isolates. J. Dairy Res. 74:452-458.

Hayes, M. G., P. F. Fox, and A. L. Kelly. 2005. Potential applications of high pressure homogenisation in processing of liquid milk. J. Dairy Res. 72:25-33.

Hayes, M. G., and A. L. Kelly. 2003a. High pressure homogenisation of milk (b) effects on indigenous enzymatic activity. J. Dairy Res. 70:307-313.

Hayes, M. G., and A. L. Kelly. 2003b. High pressure homogenisation of raw whole bovine milk (a) effects on fat globule size and other properties. J. Dairy Res. 70:297-305.

Hise, K., C. Lin, L. Zhang, P. Bordoni, L. Mauro, D. Norton, J. Sobel, A. Toguchi, S. Barth, S. Avashia, M. Richardson, L. Gaul, A. Abell, S. McAndrew, D. Rowe, W. Sorenson, M. Linn, S. Long, L. Graves, and B. Swaminathan. 2004. Laboratory investigation of a Listeria monocytogenes outbreak associated with consumption of soft cheese. P-209, page 119 in Proc. Annual Meeting of the International Association for Food Protection, Phoenix, AZ. International Association for Food Protection, Des Moines, IA.

Hnosko, J. M. 2007. High hydrostatic pressure treatment reduces levels of Listeria innocua in Queso fresco. Page 70 in Food Science and Technology. MSc Thesis. Washington State University, Pullman, WA.

Hort, J., G. Grys, and J. Woodman. 1997. The relationships between the chemical, rheological and textural properties of Cheddar cheese. Lait 77:587-600.

Hwang, C. H., and S. Gunasakaran. 2001. Measuring crumbliness of some commercial Queso Fresco-type Latin American cheeses. Milchwissenschaft 56:446-450.

Iucci, L., F. Patrignani, M. Vallicelli, M. E. Guerzoni, and R. Lanciotti. 2007. Effects of high pressure homogenization on the activity of lysozyme and lactoferrin against Listeria monocytogenes. Food Contr. 18:558-565.

Kheadr, E. E., J. F. Vachon, P. Paquin, and I. Fliss. 2002. Effect of dynamic high pressure on microbiological, rheological and microstructural quality of Cheddar cheese. Int. Dairy J. 12:435-446.

Laemmli, U. K. 1970. Cleavage of structural proteins during the assembly of the head of bacteriophage T4. Nature 227:680-685.

Lanciotti, R., C. Chaves-López, F. Patrignani, A. Paparella, M. E. Guerzoni, A. Serio, and G. Suzzi. 2004. Effects of milk treatment with dynamic high pressure on microbial populations, and lipolytic and proteolytic profiles of Crescenza cheese. Int. J. Dairy Technol. $57: 19-25$.

Lanciotti, R., F. Gardini, M. Sinigaglia, and M. E. Guerzoni. 1996. Effects of growth conditions on the resistance of some pathogenic and spoilage species to high pressure homogenization. Lett. Appl. Microbiol. 22:165-168.

Lanciotti, R., F. Patrignani, L. Iucci, M. E. Guerzoni, G. Suzzi, N. Belletti, and F. Gardini. 2007. Effects of milk high pressure homogenization on biogenic amine accumulation during ripening of ovine and bovine Italian cheeses. Food Chem. 104:693-701.

Lanciotti, R., M. Sinigaglia, P. Angelini, and M. E. Guerzoni. 1994. Effects of homogenization pressure on the survival and growth of some food spoilage and pathogenic micro-organisms. Lett. Appl. Microbiol. 18:319-322.

Lanciotti, R., L. Vannini, F. Patrignani, L. Iucci, M. Vallicelli, M Ndagijimana, and M. Elisabetta Guerzoni. 2006. Effect of high pressure homogenisation of milk on cheese yield and microbiology, lipolysis and proteolysis during ripening of Caciotta cheese. J. Dairy Res. 73:216-226.

MacDonald, P. D., R. E. Whitwam, J. D. Boggs, J. N. MacCormack, K. L. Anderson, J. W. Reardon, J. R. Saah, L. M. Graves, S. B. Hunter, and J. Sobel. 2005. Outbreak of listeriosis among Mexican immigrants as a result of consumption of illicitly produced Mexican-style cheese. Clin. Infect. Dis. 40:677-682.

Ong, L., A. Henriksson, and N. P. Shah. 2006. Development of probiotic Cheddar cheese containing Lactobacillus acidophilus, Lb. casei, Lb. paracasei and Bifidobacterium spp. and the influence of these bacteria on proteolytic patterns and production of organic acid. Int. Dairy J. 16:446-456.

Paquin, P. 1999. Technological properties of high pressure homogenizers: The effect of fat globules, milk proteins, and polysaccharides. Int. Dairy J. 9:329-335.

Pereda, J., V. Ferragut, J. M. Quevedo, B. Guamis, and A. J. Trujillo. 2007. Effects of ultra-high pressure homogenization on microbial and physicochemical shelf life of milk. J. Dairy Sci. 90:10811093.

Pereda, J., V. Ferragut, J. M. Quevedo, B. Guamis, and A. J. Trujillo. 2008. Effects of ultra-high-pressure homogenization treatment on the lipolysis and lipid oxidation of milk during refrigerated storage. J. Agric. Food Chem. 56:7125-7130.

Pereda, J., V. Ferragut, J. M. Quevedo, B. Guamis, and A. J. Trujillo. 2009. Heat damage evaluation in ultra-high pressure homogenized milk. Food Hydrocoll. 23:1974-1979.

Renye, J., G. Somkuti, B. Vallejo-Cordoba, D. Van Hekken, and A. Gonzalez-Cordova. 2008. Characterization of the microflora isolated from queso fresco made from raw and pasteurized milk. J. Food Saf. 28:59-75.

Roach, A., and F. Harte. 2008. Disruption and sedimentation of casein micelles and casein micelle isolates under high-pressure homogenization. Innov. Food Sci. Emerg. Technol. 9:1-8.

San Martin-González, F., A. Roach, and F. Harte. 2009. Rheological properties of corn oil emulsions stabilized by commercial micellar casein and high pressure homogenization. Lebenson. Wiss. Technol. 41:307-311.

Sandra, S., and D. G. Dalgleish. 2005. Effects of ultra-high-pressure homogenization and heating on structural properties of casein micelles in reconstituted skim milk powder. Int. Dairy J. 15:10951104.

Sandra, S., M. A. Stanford, and L. M. Goddik. 2004a. The use of highpressure processing in the production of Queso Fresco cheese. J Food Sci. 69:FEP153-FEP158.

Sandra, S., M. A. Stanford, M. R. McDaniel, and L. M. Goddik. 2004b. Method development for assessing the complete process of crumbling cheese using hand evaluation. J. Food Sci. 69:SNQ127SNQ130.

Taylor, T. M., A. Roach, D. G. Black, P. M. Davidson, and F. Harte. 2007. Inactivation of Escherichia coli K-12 exposed to pressures in excess of $300 \mathrm{MPa}$ in a high-pressure homogenizer. J. Food Prot. 70:1007-1010

Thiebaud, M., E. Dumay, L. Picart, J. P. Guiraud, and J. C. Cheftel. 2003. High-pressure homogenisation of raw bovine milk. Effects on fat globule size distribution and microbial inactivation. Int. Dairy J. $13: 427-439$

Tunick, M. H. 2006. Hispanic Dairy Products. Pages 33-43 in Hispanic Foods. Vol. 946. M. H. Tunick and E. González de Mejia, ed. American Chemical Society, Washington, DC.

USDA-NASS. 2010. Dairy Products, 2009 Summary. Vol. 2010. National Agricultural Statistics Service (NASS), Washington, DC.

Van Hekken, D. L., and N. Y. Farkye. 2003. Hispanic cheeses: The quest for queso. Food Technol. 57:32-38.

Vannini, L., F. Patrignani, L. Iucci, M. Ndagijimana, M. Vallicelli, R. Lanciotti, and M. E. Guerzoni. 2008. Effect of a pre-treatment of milk with high pressure homogenization on yield as well as on microbiological, lipolytic and proteolytic patterns of "Pecorino" cheese. Int. J. Food Microbiol. 128:329-335

Villar, R. G., M. D. Macek, S. Simons, P. S. Hayes, M. J. Goldoft, J. H. Lewis, L. L. Rowan, D. Hursh, M. Patnode, and P. S. Mead. 1999. Investigation of multidrug-resistant Salmonella serotype Typhimurium DT104 infections linked to raw-milk cheese in Washington State. JAMA 281:1811-1816.

Wuytack, E. Y., A. M. J. Diels, and C. W. Michiels. 2002. Bacterial inactivation by high-pressure homogenisation and high hydrostatic pressure. Int. J. Food Microbiol. 77:205-212.

Zamora, A., V. Ferragut, P. D. Jaramillo, B. Guamis, and A. J. Trujillo. 2007. Effects of ultra-high pressure homogenization on the cheese-making properties of milk. J. Dairy Sci. 90:13-23. 